\title{
Relationship of activities in reverse logistics according to sell point in Czech Republic
}

\author{
František Milichovský ${ }^{1, *}$ \\ ${ }^{1}$ Doctor of Economics and management, Assistant Professor, Brno university of Technology, Faculty \\ of Business and Management, Department of Management, Kolejní 2906/4, CZ-61200 Brno, Czech \\ Republic
}

\begin{abstract}
The paper is focused on findings, if final customers in sell points reflect activities of reverse logistics. Main result of research provides relationship between sell point and reverse activity. The research was aimed at random chosen group of 811 respondents in the Czech Republic. Real participants have been 293, what is effectiveness in $36.13 \%$. The primary research provides possible approaches for companies in sell points within reverse logistics activities to final consumers. To process the results of the questionnaire survey were used basic types of descriptive statistics on the selected data set. The data were processed by using the statistical program IBM SPSS Statistics 24, which was subsequently analysed the dependency between the two nominal variables by means of contingency tables and Pearson's chi-squared test. Limitation for this research is because of the chosen sample and targeting only on Czech Republic.
\end{abstract}

Key words: Reverse logistics, marketing communication, green communication

\section{Introduction}

On the grounds of the market globalization of all markets larger competitive environments have been created and higher pressure is put onto offered values - especially quality, price and production quantity [1]. Therefore, companies must focus on monitoring of effective realization of all activities (especially in marketing, business and reverse logistics). Based on these reasons the companies must focus on monitoring of effective realization of marketing activities.

Effectiveness of company has become one of the important part of corporate sustainability, on which each company focus on. Therefore, fundamental of each corporate strategy is success, which is supported by marketing and business. Strategy of every company deals with many cultural differences that are essential for understanding of different culture.

These conditions create necessity of implementation of supply chain management with individual activities, which would be win-win for both of seller and customer. In supply

\footnotetext{
*Corresponding author: milichovsky@fbm.vutbr.cz
} 
chain management there is possible to consider reverse logistics as key part for global sustainability and building competitive advantages in the markets [2], [3], [4], [5], [6].

\section{Theoretical background}

Logistics itself has become more significant in present day because there is necessary to link three corporate fields together. These fields are marketing activities, production management and corporate financing, where logistics provides required flows - such material and product, information and financial. All logistics flows help to allocate every sources, which are important for effective processes [7].

Logistics has become process by which is distributed product from producer to final customer. From point of view of used material, this process started within raw material. That could be called as typical logistics chain (or supply chain) Main problem in logistics chains is, what to do with waste in production process, used packaging of new products and old products [8].

According to Ferrer \& Whybark [9] there is necessary to use garbage as the way of gaining material sources instead of their stocking or burning (impact on nature environment). Waste problems could be solved by reverse logistics (RL) which requires adequate skills, capabilities, market awareness, and staff with experiences [10]. Reverse logistics (RL) has become important part of marketing activities from logistic point of view. It is usually located in the end of whole marketing loop where is after-sale phase defined. RL itself is difficult to describe because of applying individual activities in all phases. RL is process of moving products from place of typical usage for recapturing value or any other disposal [11], [12].

There is difficult to define exact list of RL activities. Abdulah \& Yaakub [13] mention main groups of activities which are considered in RL. These groups are: (A) product returns, (B) disposition, (C) green manufacturing, (D) recycle, (E) refurbishing, (F) landfill, (G) salvage, (H) remanufacturing. Similar groups of RL's activities are described by Nikolaidis [14]. However, in comparison with Abdulah \& Yaakub [13] he defines only seven groups in different way: (A) landfilling, (B) recycling, (C) cannibalization, (D) remanufacturing, (E) refurbishing, (F) repairing, (G) direct reuse or resale. Appropriate connection of logistics and marketing should be crucial for company.

Final consumers begin to look forward products with correct production such bioproduction or green labelling [15]. According to requirements of green supply-chain management, Hervani et al. [16] define as the most significant RL activities (1) reuse, (2) remanufacturing, (3) recycling. Green corporate activities (e.g. production, marketing) are very important from point of view of sustainability [4]. Green marketing as part of RL is focused on bio-products, low operational costs and products of biodegradable waste [17].

By using information of technology development in marketing campaigns, sellers want to increase own income (especially for electronic products). These products have high influence of innovation cycle [18], [19]. Customers still require new products to replace old ones, and they are more interesting in alternative of landfilling. Almost all products need more natural re-sources and energy to make new ones. Electronic devices have become distinguished because of the low life cycle and non-friendly wastes [20].

RL itself has become part of sustainable industrial marketing because of the necessity of destroying of packaging and the rest of used materials. Main problem could be how these materials would be collected from the customers to applying RL activities. Therefore, there are compare both economic and ecological aspects of possible processing [21], [22]. RL activities and their realization need knowledge management and adequate experiences in all phases [23], [24], [25]. 
Usually, all activities in reverse logistics are applied in corporate campaigns which provides to customers relevant emotion for purchase. This emotion is depending on various conditions such sex, age, kind of product, region and their needs. Specific emotions for purchase is hope of high quality products or fear of unknown [26].

Schmitt [27] and Alkilani, Ling, Abzakh [28] propose the concept of strategic experiential modules that aims to help the marketers to create alternative types of customer experiences. The experiential modules managed by the experiential marketing include: sensory experiences (sense); affective experiences (feel); creative cognitive experiences (think); physical experiences, behaviours and lifestyles (act) and social-identity experiences that result from relating to a reference group or culture (relate). Schmitt [27] and Smilansky [29] add that the purpose of experiential marketing is to create holistically integrated experiences that possess, at the same time, sense, feel, think, act and relate qualities. Lee, Hsiao, Yang [30] mention that experiential marketing can be related to the customer satisfaction.

As way of building competitiveness, companies must focus on long-time period from marketing perspective. Complex manufacturing process need to be innovated in various ways - improving or changing technology of production, changing used material and others. They need to do production strategy in cooperation marketing strategy [31], [32]. Present trend for consumer products is Eco-friendly categorization, what means, that the products are dissoluble in nature by common ways. Perception of marketing campaigns includes many differences, especially from demographic point of view. The reason for this difference could come out mainly from demographic variables [33]: (1) female consumers are more interested in both expressive and functional aspects than males; (2) people with higher income pay more attention to functionalities, ease of use, and quality); (3) people with higher education put less significance to symbolic aspects in purchasing. One of the most important perspectives is gender on which many marketing campaigns focus on [34], [35], [36], [37]. All demographic factors impact corporate marketing activities, mainly in connection with launching new products, for which have become defined basic market segments with possible high income.

\section{Applied Methodology}

The main aim of this paper is to identify level of influence of reverse logistics' activities in connection with marketing communication in Czech business environment. Main hypothesis is that there is dependence between in sell-places and application of reverse logistics (reverse logistics has becomes very important part for decision making process of purchasing). Main hypothesis is that there is closed relations in their connection. Presented paper is based on primary research by questionnaire survey, conducted in 2016, focused on activities of reverse logistics in connection within purchase place. To process the results of the questionnaire survey there were used both of descriptive statistics and correspond analysis. The conclusions provide characteristics of the limitations of the research and its potential further direction. Sample population was created by 811 consumers, which were chosen in random way. There were returned questionnaires from 293 respondents (effectiveness was $36.13 \%$ ). To process the results of the questionnaire survey were used basic types of descriptive statistics on the selected data set. The data were processed by using the statistical program IBM SPSS Statistics 24 , which was subsequently analyzed the dependency between the two nominal variables by means of contingency tables and Pearson's chi-squared test. 


\section{Results}

Based on the analysis of descriptive statistical characteristics of the sample (Mean, Median, and Values of Variability), conclusions will be presented merely as an explorative result limited by the resultant reliability. The conclusion provides characteristics of the limitations of research and its potential further direction. According to descriptive statistics of gained responses it is obvious, that customers are interesting in returns $(\bar{x}=7,31)$, changes $(\bar{x}=$ $7,58)$ and repairs $(\bar{x}=7,64)$ of purchased products. They care about self-profit, but they do not care where the product is bought (see Table 1). For purpose of the paper there is necessary to design, what kind of sell-points have impact on activities in reverse logistics. Due the aim of the paper, an analysis of dependency of variables was carried out only between performance in marketing field and reverse logistics activities. In order to establish the dependency test, statistical testing using Pearson chi-square test was used.

Table 1. Descriptive statistics of variables

\begin{tabular}{|l|c|c|c|c|}
\hline & Mean & Median & $\begin{array}{c}\text { Std. } \\
\text { deviation }\end{array}$ & Variance \\
\hline Return of purchased products & 7.31 & 8.00 & 2.877 & 8.276 \\
\hline Change of purchased products & 7.58 & 8.00 & 2.316 & 5.365 \\
\hline Return of old products & 4.81 & 5.00 & 2.885 & 8.321 \\
\hline Repair of purchased product & 7.64 & 8.00 & 2.490 & 6.202 \\
\hline Reverse taking of packaging & 2.92 & 2.00 & 2.550 & 6.501 \\
\hline General retail & 1.67 & 2.00 & .911 & .830 \\
\hline Specialized retail & 1.72 & 2.00 & .864 & .746 \\
\hline Electronic shop & 2.02 & 2.00 & 1.092 & 0.934 \\
\hline Market & 0.88 & 1.00 & 1.192 & 0.873 \\
\hline Mail-order store & 1.26 & 1.00 & 1.031 & 1.063 \\
\hline
\end{tabular}

Source: Author.

In further analysis, there was applied analysis of dependency between individual variable groups (sell-points, reverse logistics' activities). In order to establish the dependency test, statistical testing using chi-square test was used.

The results of the dependency test are provided in Table 2 which examines the dependency between reverse logistics' activities and sell-points. The results of the dependency examination in individual variable categories are depicted in the following results of Pearson's chi-square test. According to these values there were find out fifteen dependencies from twenty-five relations. 
Table 2. Results of Pearson's test between individual variables

\begin{tabular}{|c|c|c|c|c|c|c|}
\hline & & 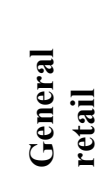 & 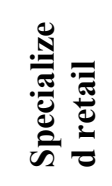 & 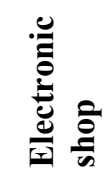 & 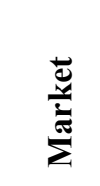 & 宸窇 \\
\hline \multirow{2}{*}{$\begin{array}{l}\text { Return of } \\
\text { purchased } \\
\text { products }\end{array}$} & Pearson $\chi^{2}$ & 0.148 & 0.147 & 0.495 & 0.000 & 0.037 \\
\hline & Contingency coef. & 0.519 & 0.518 & 0.484 & 0.678 & 0.546 \\
\hline \multirow{2}{*}{$\begin{array}{l}\text { Change of } \\
\text { purchased } \\
\text { products }\end{array}$} & Pearson $\chi^{2}$ & 0.040 & 0.574 & 0.097 & 0.020 & 0.018 \\
\hline & Contingency coef. & 0.529 & 0.447 & 0.518 & 0.544 & 0.541 \\
\hline \multirow{2}{*}{$\begin{array}{l}\text { Return of old } \\
\text { products }\end{array}$} & Pearson $\chi^{2}$ & 0.000 & 0.025 & 0.238 & 0.004 & 0.000 \\
\hline & Contingency coef. & 0.614 & 0.552 & 0.513 & 0.581 & 0.624 \\
\hline \multirow{2}{*}{$\begin{array}{l}\text { Repair of } \\
\text { purchased } \\
\text { product }\end{array}$} & Pearson $\chi^{2}$ & 0.006 & 0.338 & 0.012 & 0.026 & 0.028 \\
\hline & Contingency coef. & 0.559 & 0.475 & 0.558 & 0.523 & 0.535 \\
\hline \multirow{2}{*}{$\begin{array}{l}\text { Reverse } \\
\text { taking of } \\
\text { packaging }\end{array}$} & Pearson $\chi^{2}$ & 0.007 & 0.000 & 0.243 & 0.214 & 0.063 \\
\hline & Contingency coef. & 0.575 & 0.627 & 0.515 & 0.514 & 0.539 \\
\hline
\end{tabular}

Source: Author.

By maintaining percentage reliability of the Pearson's chi-square test, there was compared significance of the test with theoretical value 0.05 , which represents $5 \%$ reliability level (if is accepted alternate hypothesis, than there is $5 \%$ probability of error). According to this condition, there were observed fifteen dependencies, which brings the conclusion that an alternative hypothesis applies. Other relations have not confirmed the dependency (individual significance is over 0.05). Subsequently, the degree of such dependency was examined. To that end, the intensity of dependency determined by means of contingency coefficient as per formula (1) was used.

$$
C_{p}=\sqrt{\frac{\chi_{p}^{2}}{\chi_{p}^{2}+n}}
$$

where $C_{p}$ is contingency coefficient; $n$ represents number of cases; $\chi^{2}$ is Pearson's chi square test

The intensity of dependency ranges between $\langle 0 ; 1\rangle$, what means that as observed figure as is closed to 1 , then is considered as dependence. In the level of $95 \%$ confidence, the gained values of individual pairs are (according to Table 2):

- $\quad$ Return of purchased products is depended on Market $\left(\chi^{2}=0.000, \mathrm{C}_{\mathrm{p}}=0.678\right)$ and Mail-order store $\left(\chi^{2}=0.037, \mathrm{C}_{\mathrm{p}}=0.546\right)$;

- Change of purchased products is depended on General retail $\left(\chi^{2}=0.040, \mathrm{C}_{\mathrm{p}}=\right.$ $0.529)$, Market $\left(\chi^{2}=0.000, \mathrm{C}_{\mathrm{p}}=0.678\right)$ and Mail-order store $\left(\chi^{2}=0.037, \mathrm{C}_{\mathrm{p}}=\right.$ $0.546)$;

- $\quad$ Return of old products is depended on General retail $\left(\chi^{2}=0.000, C_{p}=0.614\right)$, Specialized retail $\left(\chi^{2}=0.025, \mathrm{C}_{\mathrm{p}}=0.552\right)$, Market $\left(\chi^{2}=0.004, \mathrm{C}_{\mathrm{p}}=0.581\right)$ and Mail-order store $\left(\chi^{2}=0.000, C_{p}=0.624\right)$; 
- $\quad$ Return of old products is depended on General retail $\left(\chi^{2}=0.000, C_{p}=0.614\right)$, Specialized retail $\left(\chi^{2}=0.025, C_{p}=0.552\right)$, Market $\left(\chi^{2}=0.004, C_{p}=0.581\right)$ and Mail-order store $\left(\chi^{2}=0.000, C_{p}=0.624\right)$;

- Reverse taking of packaging is depended on General retail $\left(\chi^{2}=0.007, \mathrm{C}_{\mathrm{p}}=\right.$ $0.575)$, and Specialized retail $\left(\chi^{2}=0.000, C_{p}=0.627\right)$.

All relations between purchase places and reverse logistics activities are designed in Figure 1. In these connection are showed dependency value and in brackets contingency coefficient. Contingency coefficient describes the intensity between individual variables.

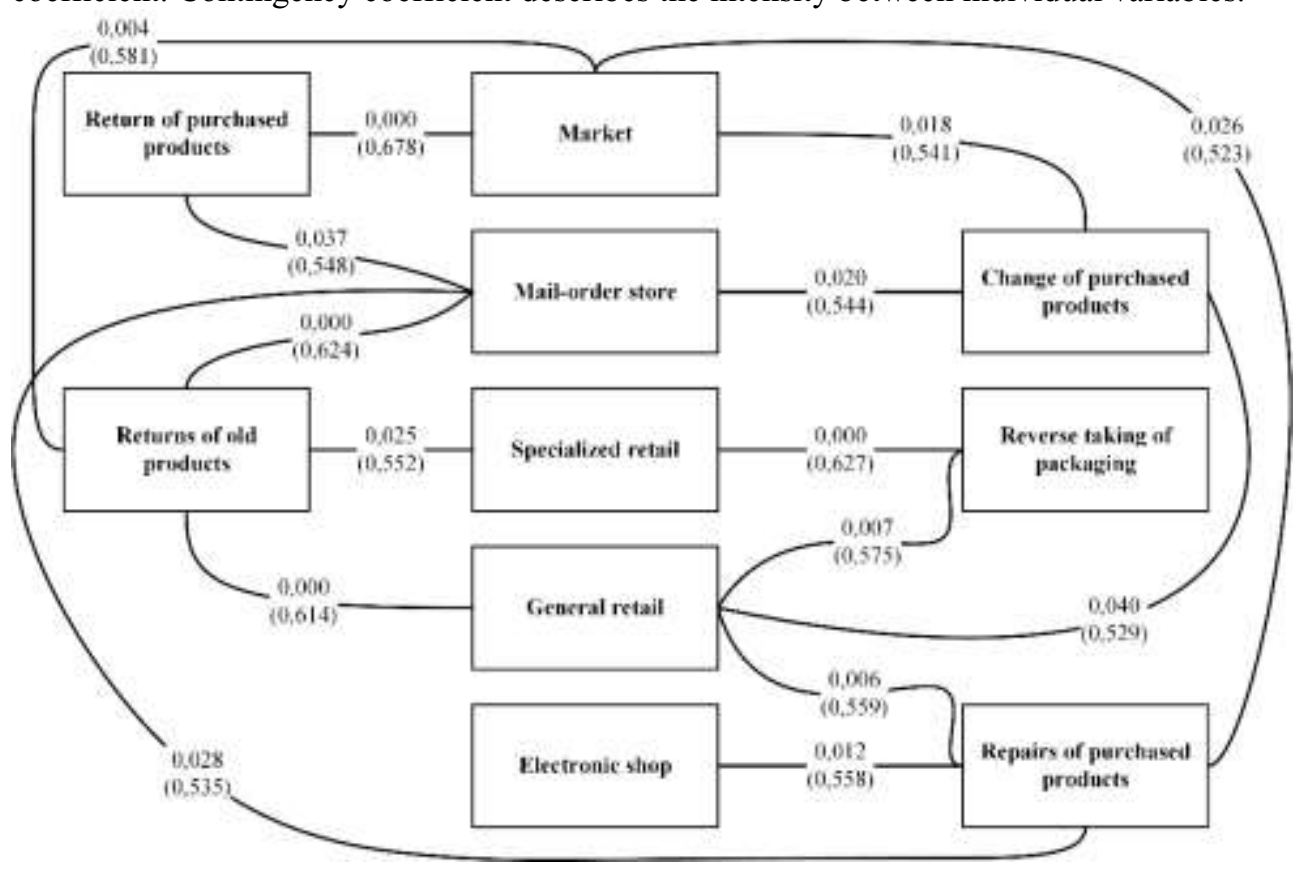

Fig. 1. Dependencies between reverse logistics and sell place

Source: Author.

\section{Conclusion}

Nowadays, reverse logistics has become one of the crucial aspect of business environment around the world. Several authors consider, that environmental issues in both of business and consumption life are closely connected within responsibility by individual chains in supply chain management (e.g. [38], [39]).

Zaman and Shamsuddin [38] discuss, that activities in supply chain processes are closely related to environmental quality and induce unhealthy environment (for business and living). As unhealthy they consider profit oriented approach in comparison with social oriented approach as healthy and sustainable way for the all countries.

Business activities and reverse logistics are closely interlinked areas that need to be addressed by businesses (manufacturers, retailers, customers) as well as end-users. The topicality of the whole topic reflects all requirements for the efficiency of enterprises in the use of production resources. The efficient use of production resources will minimize the generation of waste from the used production material and at the same time from the used packaging. The issue of used waste is a very serious problem, which results in a significant disturbance of the environment in the form of soil, water and air pollution (in case of 
landfilling) or in the case of combustion is the release of hazardous fumes [40]. Linking these business areas and reverse logistics activities can achieve the desired efficiencies at all levels (both customer and retailer).

\section{References}

1. T. Ambler, Market metrics: What should we tell the shareholders? The Journal of Risk Finance, 10(1), 47-50, (2002)

2. V. Guide, L. N. Van Wassenhove, The reverse supply chain. Harvard Business Review, 80(2), 25-26, (2002)

3. M. A. Lapré, A. S. Mukherjee, L. N. Van Wassenhove, Behind the learning curve: linking learning activities to waste reduction. Management Science, 46(5), 597-611, (2000)

4. J. Hornungová, M. Klímková, The Relationship of Environmental and Economic Performance. Scientia \& Societas, 9(4), 207-217, (2013)

5. M. Pagell, Z. Wu, Building a more complete theory of sustainable supply chain management using case studies of 10 exemplars. Journal of Supply Chain Management, 45(2), 37-56, (2009)

6. R. Dahlstrom, Green marketing management. Mason: South-Western Cengage Learning, (2011)

7. P. Pernica, Logistika: Supply Chain Management. Praha: Radix, (2005)

8. K. Govindan, H. Soleiman, D. Kannan, Reverse Logistics and Closed-Loop Supply Chain: A Comprehensive Review to Explore the Future. European Journal of Operational Research, 240(3), 603-626, (2015)

9. G. Ferrer, C. D. Whybark, From Garbage to Goods: Successful Remanufacturing Systems and Skills. Business Horizons, 43(6), 55-64, (2000)

10. R. Giuntini, K. Gaudette, Remanufacturing: The Next Great Opportunity for Boosting US Productivity. Business Horizons, 46(6), 41-48, (2003)

11. S. E. Genchev, Reverse Logistics Program Design: A Company Study. Business Horizons, 52(3), 139-148, (2009)

12. P. J. Daugherty, R. G. Richey, S. E. Genchev, H. Chen, Reverse logistics: Superior Performance Through Focused Commitments to Information Technology. Transportation Research Pert E, 41, 77-92, (2005)

13. N. H. N. Abdullah, S. Yaakub, Reverse Logistics: Pressure for Adoption and the Impact on Firm's Performance. International Journal of Business and Society, 15(1), 151-170, (2014)

14. Y. Nikolaidis, Quality management in Reverse Logistics: A Broad Look on Quality Issues and Their Interaction with Closed-Loop Supply Chain. London: Springer, (2013)

15. G. Tomek, V. Vávrová, Marketing: Od myšlenky $k$ realizaci. 3rd ed. Praha: Professional Publishing, (2011)

16. A. A. Hervani, M. M. Helms, J. Sarkis, Performance Measurement for Green Supply Chain Management. Benchmarking: An International Journal, 12(4), 330-353, (2005)

17. L. C. M. Holanda, A. C. Francisco, Consumer's Perception of the Products Made with Recycled Components: Case Study from the Course of Administration of the Faculty of Campina Grande - FAC. Espacios, 34(10), 1-9, (2013) 
18. B. Lebreton, A. Tuma, A Quantitative Approach to Assessing the Profitability of Car and Truck Tire Remanufacturing. International Journal of Production Economics, 104(2), 639-652, (2006)

19. Ch.-F. Hsueh, An Inventory Control Model with Consideration of Remanufacturing and Product Life Cycle. International Journal of Production Economics, 133(2), 645652, (2011)

20. S. S. Gan, I. N. Pujawan, Suparno, B. Widodo, Pricing Decision Model for New and Remanufactured Short-life Cycle Products with Time-dependent Demand. Operation Research Perspectives, 2, 1-12, (2015)

21. C. K. M. Lee, J. S. L. Lam, Managing Reverse Logistics to Enhance Sustainability of Industrial Marketing. Industrial Marketing Management, 41(4), 589-598, (2012)

22. A. El Korchi, D. Miller, Designing a Sustainable Reverse Logistics Channel: The 18 Generic Structures Framework. Journal of Cleaner Production, 19(6-7), 588-597, (2011)

23. S. Wadhwa, J. Madaan, Intelligent agent technology for reverse logistics. Information Control Problems in Manufacturing, 12(1), 215-220, (2006)

24. S. Wadhwa, J. Madaan, Role of Quality Management Self-Assessment Model to Promote Reverse Logistics Operations. Bangkok: International Conventions on Quality Control Circles, (2004)

25. A. Mihi Ramirez, L. Girdauskiene, Creation of knowledge and reverse logistics: Empirical analysis from perspective of the reverse based view theory. Engineering Economics, 24(5), 478-487, (2013)

26. Y.-K. Lee, C.-T. Chang, P.-C. Chen, What sells better in green communications: Fear of Hope. It Depends on Whether the Issue Is Global or Local. Journal of Advertising Research, 57(4), 379-396, (2017)

27. B. Schmitt. Experiential Marketing: How to Get Customers to Sense, Feel, Think, Act, Relate to Your Company and Brands. New York: The Free Press, (1999)

28. K. Alkilani, K. C. Ling, A. A. Abzakh. The Impact of Experiential Marketing and Customer Satisfaction on Customer Commitment in the World of Social Networks. Asian Social Science, 9(1), 262-270, (2013)

29. S. Smilansky. Experiential marketing: A practical guide to interactive brand experiences. London: Kogan Page, (2009)

30. M. S. Lee, H. D. Hsiao, M. F. Yang, The study of the relationships among experiential marketing, service quality, customer satisfaction and customer loyalty. The International Journal of Organizational Innovation, 3(2), 353-379, (2011)

31. S. W. O'leary-Kelly, B. E. Flores, The integration of manufacturing and marketing/ sales decisions: Impact on organizational performance. Journal of Operational Management, 20, 221-240, (2002)

32. D. Pollard, I. Šimberová, Marketing in high-technology firms. 7th International scientific conference business and management 2012, 465-471, (2012)

33. A. Toppinen, R. Toivonen, A. Valkeapää, A.-K. Rämö, Consumer Perceptions of Environmental and Social Sustainability of Wood Products in the Finnish Market. Scandinavian Journal of Forest Research, 28(8), 775-783, (2013)

34. E. Ambrozová, V. Pokorný, Ke změnám v myšlení lidí v lidských systémech z hlediska management. Scientia \& Societas, 8(3), 139-152, (2012) 
35. S. Rahmani, M. G. Lavasani, Gender Differences in Five Factor Model of Personality and Sensation Seeking. Procedia - Social and Behavioral Sciences, 46, 2906-2911, (2012)

36. P. J. Costa, A. Terracciano, R. R. McCrae, Gender Differences Personality Traits Across Cultures: Robust and Surprising Findings. Journal of Personality and Social Psychology, 81(2), 322-331, (2001)

37. W.-J. He, W.-C. Wong, Gender Differences in Creative Thinking Revisited: Findings from Analysis of Variability. Personality and Individual Differences, 51(7), 807-811, (2011)

38. K. Zaman, S, Shamsuddin, Green logistics and national scale economic indicators: Evidence from a panel of selected European countries. Journal of Cleaner Production, 143, 51-63, (2017)

39. C. Altuntas, O, Tunas, Greening Logistics Centers: The Evolution of Industrial Buying Criteria Towards Green. The Asian Journal of Shipping and Logistics, 29(1), 59-80, (2013)

40. Eurostat. Statistika odpadi. [online] Available at: http://ec.europa.eu/eurostat/statisticsexplained/index.php/Waste statistics/cs (2017) 